\title{
Thymosin Beta-4, Y-Chromosomal
}

National Cancer Institute

\section{Source}

National Cancer Institute. Thymosin Beta-4, Y-Chromosomal. NCI Thesaurus. Code C137964.

Thymosin beta-4, Y-chromosomal ( $44 \mathrm{aa}, \sim 5 \mathrm{kDa}$ ) is encoded by the human TMSB4Y gene. This protein is involved in the inhibition of actin polymerization. 